\title{
Reasons assigned to suicide attempts: adolescents' perceptions
}

\author{
Motivos atribuídos às tentativas de suicídio: percepção dos adolescentes \\ Motivos atribuidos a intentos de suicidio: percepción de adolescentes
}

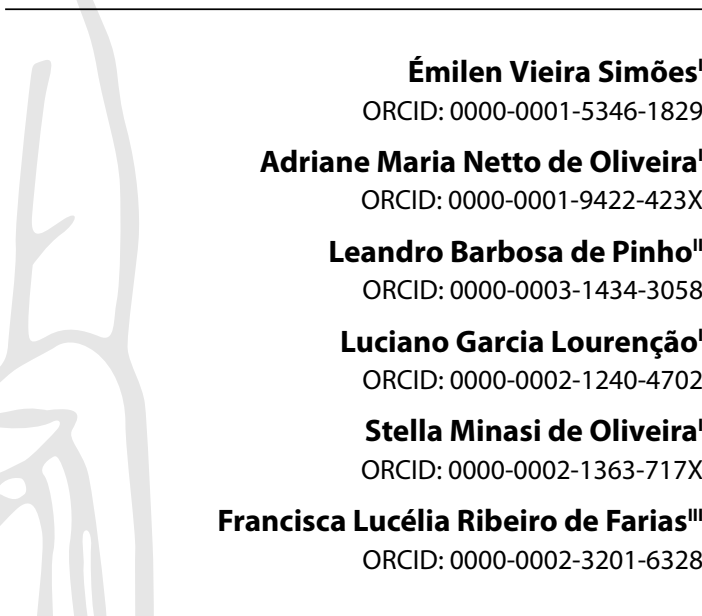

'Universidade Federal do Rio Grande. Rio Grande, Rio Grande do Sul, Brazil. "Universidade Federal do Rio Grande do Sul. Porto Alegre, Rio Grande do Sul, Brazil I'Universidade de Fortaleza. Fortaleza, Ceará, Brazil.

How to cite this article: Simões EV, Oliveira AMN, Pinho LB, Lourenção LG, Oliveira SM, Farias FLR. Reasons assigned to suicide attempts: adolescents' perceptions. Rev Bras Enferm. 2022;75(Suppl 3):e20210163. https://doi.org/10.1590/0034-7167-2021-0163

\section{Corresponding author:}

Émilen Vieira Simões

E-mail:emi-dp@hotmail.com

EDITOR IN CHIEF: Antonio José de Almeida Filho ASSOCIATE EDITOR: Hugo Fernandes

\section{ABSTRACT}

Objective: identify the reasons for attempting suicide from the perspective of adolescents. Methods: qualitative study conducted with ten adolescents who attempted suicide and were attending a Centro de Atenção Psicossocial Infanto-Juvenil located in a city in the south of Brazil. Semi-structured interviews were held in July 2020 using WhatsApp. Data were analyzed according to Minayo's Content Thematic Analysis. Results: the adolescents'reports listed the reasons that triggered suicide attempts, such as changes in the adolescents'life cycle and violence, which led them to attempt suicide to solve problems. Final considerations: Data analysis revealed the reasons that triggered suicide attempts from the adolescents' perspective and difficulties to cope with problems, probably explained by their lack of experience in dealing with frustrations and disappointments.

Descriptors: Suicide; Adolescent; Perception; Mental Health; Nursing.

\section{RESUMO}

Objetivo: Identificar os motivos atribuídos às tentativas de suicídio na percepção dos adolescentes. Métodos: Pesquisa qualitativa, realizada com 10 adolescentes que tentaram o suicídio e foram atendidos em um Centro de Atenção Psicossocial Infantojuvenil de um município do Sul do Brasil. Os dados coletados por meio de entrevistas semiestruturadas, realizadas em julho de 2020, via aplicativo WhatsApp, foram analisados conforme análise temática de conteúdo de Minayo. Resultados: Foi possível identificar, nas falas dos adolescentes, os motivos desencadeadores das tentativas de suicídio, tais como mudanças no ciclo de vida e violência, em busca de uma solução para os problemas que os afligiam. Considerações finais: Ficou evidente a notória dificuldade de enfrentamento dos problemas vivenciados entre os adolescentes, provavelmente, também, pela inexperiência em lidar com as frustrações e decepções da vida.

Descritores: Suicídio; Adolescente; Percepção; Saúde Mental; Enfermagem.

\section{RESUMEN}

Objetivo: identificar los motivos atribuidos a intentos de suicidio en la percepción de adolescentes. Métodos: investigación cualitativa, realizada en 10 adolescentes, que practicaron intentos de suicidio, atendidos en un Centro de Atenção Psicossocial Infanto-Juvenil, en un municipio del sur de Brasil. Las entrevistas fueron semiestructuradas y realizadas en julio de 2020, a través del aplicativo Whatsapp. Los datos fueron analizados de acuerdo al análisis temático de contenido de Minayo. Resultados: fue posible identificar a través de las declaraciones de los adolescentes, los motivos que desencadenaron los intentos de suicidio; por ejemplo, los cambios en el ciclo de vida del adolescente y la violencia, lo que llevó a los intentos de suicidio como siendo la solución para sus problemas. Consideraciones finales: el análisis de los datos permitió identificar: los motivos atribuidos a los intentos de suicidio por los adolescentes; la dificultad para enfrentar los problemas experimentados; $y$, probablemente también, por la inexperiencia en administrar las frustraciones y decepciones de la da vida. Descriptores: Suicidio; Adolescente; Percepción; Salud Mental; Enfermería. 


\section{INTRODUCTION}

Adolescence is centered on biopsychosocial development, the construction of maturity to establish interpersonal relationships, choosing one's professional occupation, and identity formation. Based on the new demands of this stage of life, adolescents generally seek to adapt to different contexts, using personal resources and social skills acquired throughout their development ${ }^{(1)}$.

For feeling unheard, unrecognized, or often due to difficulty verbally expressing feelings, adolescents manifest themselves non-verbally. As a result, inappropriate behavior may be adopted in an attempt to show that something is not well or that they are not receiving proper attention, understanding, or the affection they need and would like to receive from their families and society. During adolescence, individuals are impulsive and usually have a sense of urgency, and sometimes when they do not feel they belong to a social context, the only alternative they envision to solve problems is to put an end to their lives, that is, put an end to their psychological pain ${ }^{(2)}$.

Many times adolescents adopt risk-taking behaviors, not realizing the danger of situations, and for this reason, risk their lives by getting involved with violence, suicide games, or going to parties where legal and illegal drugs are freely consumed. These situations coupled with internal factors, like excessive anxiety, anguish, or personal conflicts involving self-esteem and self-image, and external factors such as family or social conflicts, may lead them to attempt suicide. The consequences of problems individuals experience throughout their development, mainly estranged or conflicting relationships, traumas, and violence, allied with their way of being, may trigger mental disorders, most frequently, depressive disorder. Difficulties to socially interact and hopelessness is also often related to suicide attempts.

According to the Pan American Health Organization, suicide is the third leading cause of death among 15-19-year-olds; 62,000 adolescents are estimated to die worldwide due to self-inflicted injuries ${ }^{(3)}$. In Brazil, 1,047 deaths occurred in 2017 due to self-injuries among children and adolescents aged between 10 and 19; 80 deaths occurred in this age range in Rio Grande do Sul only(4).

To better understand suicide attempts among adolescents, this study was conducted in a city located in the extreme south of Brazil, asking the following question: What are the reasons adolescents attempt suicide?

\section{OBJECTIVE}

To identify the reasons for attempting suicide from the adolescents' perspective.

\section{METHODS}

\section{Ethical Aspects}

Regarding ethical principles, Resolution No. 466, from December $12^{\text {th }}, 2012$, from the Conselho Nacional de Saúde and Resolution No. 510, from April 7th, 2016, from the Conselho Nacional de Saúde, Ministério da Saúde (CNS/MS), regulating research with human subjects were complied with integrally. Additionally, the study was approved by the Institutional Review Board at the Federal
University at Rio Grande (CEP/FURG), and the Núcleo Municipal Educação em Saúde (NUMESC) at Rio Grande.

\section{Study design}

This qualitative study originated from the Master's thesis "Visibility of the attempt(s) of suicide from the discourses of teenagers", exploratory and descriptive in nature. The qualitative approach comprises the universe of meanings, reasons, aspirations, beliefs, values, and attitudes that cannot be reduced to the operationalization of variables and are directly connected to interactions established among people ${ }^{(5)}$. This study's exploratory expectations concern the reasons adolescents assign to suicide attempts. The COREQ script was used to report data.

\section{Methodological Procedures}

\section{Study setting}

The study's setting was the Centro de Atenção Psicossocial InfantoJuvenil (CAPS i) [Child and Adolescent Psychosocial Care Center] located in Rio Grande in the south of Brazil. It was established on December $17^{\text {th }}, 2009$, to meet the specific needs of children and adolescents up to 17 years old. According to SUS principles, it is a psychosocial care facility with community characteristics of daily healthcare service provided in an extra-hospital setting. Universal access is guaranteed, and the target population comprises children and adolescents with severe mental disorders, including the patients families in the treatment. This health device provides therapeutic interventions, including individual and group sessions, therapeutic workshops, family care, home visits, and social and school reintegration support. During the COVID-19 pandemic, CAPS i started providing care online to 17 adolescents who attempted suicide. These were the adolescents invited to participate in this study.

\section{Data source}

Ten adolescents met the inclusion criteria and were included in this study: attending support groups and online sessions, having attempted suicide, and being aged between 10 and 17 years, 11 months, and 29 days old (age limit for being cared for by CAPS i). Exclusion criteria were: attending group sessions for less than three months because these individuals were still adapting to the treatment and for this reason were considered unable to talk about themselves.

The 17 adolescents receiving online care were contacted, and ten consented to participate. Three did not accept to participate due to personal reasons; the parents of one adolescent did not authorize his participation for believing their child was not apt to talk about suicide; one adolescent had run away from home, and one adolescent was excluded because she was not able to answer for herself. Hence, a total of ten adolescents who attempted suicide composed the final sample.

\section{Data collection}

Data were collected remotely using a semi-structured interview through video or audio calls using WhatsApp in July 2020. 
The semi-structured script contained 19 open-ended questions that allowed participants to talk and express themselves freely. Four questions were asked to meet the study's objective, addressing the participants' perceptions of suicide: When did you start experiencing depressive symptoms?; What was the main reason you attempted to take your life?; How many times did you attempt to take your life, and what means did you use?; Why did you consider suicide was the solution for your problems?

The reports were recorded and transcribed verbatim to ensure the veracity of data. All the parents and legal guardians authorized the adolescents to participate in the study and audio recording via WhatsApp after reading free and informed consent forms. After their parents, all the adolescents also provided their consent to record the calls and agreed with the informed consent document.

The interviews lasted from 15 to 50 minutes, but most lasted 30 minutes on average. The interviewer held the interviews from a room with a calm environment, free of noise, where the decoration made the room look cozy, with an armchair, plants, and other items intended to make the participants feel safe. Confidentiality of information was also ensured. The objective was to let the adolescents see the interviewer in a calm environment so they would feel safe and comfortable to answer the questions during the audio/video calls. The adolescents answered the calls in their bedrooms, alone, and no one like mother, father, or siblings living in the same home interfered with the conversation. The participants are identified by the letter " $A$ " (which stands for adolescent) followed by the letter " $M$ " (male) or " $F$ " (female) as self-reported to preserve their participants' identities.

The researchers was not trained before the online interviews, which possibly resulted in some gaps; however, the primary author is experienced with suicide prevention, has received training in the remote delivery of healthcare, and has experience working with students in mental health services. Additionally, the interviewer worked with adolescents during her academic training and developed skills that enabled her to establish rapport with this population. Based on knowledge exchanged during the study, coupled with trust established with the participants, she achieved the study's objective.

\section{Data analysis}

Data were analyzed according to Thematic Content Analysis from Minayo's perspective ${ }^{(5)}$. This method is defined as a set of techniques used to analyze communication. Discourse analysis supports the construction of knowledge, focused not only on the meaning of words but also on implicit messages. The thematic analysis comprises three stages: the first stage refers to the preanalysis, in which the reports are read in detail, guided by the study's objective. According to the topic, new situations may emerge, then be analyzed considering the literature's results. The second stage refers to material exploration and categorization by grouping similarities and differences identified in the adolescents' reports. Finally, the third stage refers to the treatment and interpretation of data. Data gathered in this stage were related and interpreted based on other authors addressing this research topic, revealing the meanings and results considering the participants' reports.
The adolescents and the professionals from CAPS i were invited to participate in an online ceremony open to the public in which the results were presented. The participants' knowledge was also highlighted as it enabled exchanging knowledge and improving care.

Two categories emerged from the analysis: Changes in the adolescents'life cycle and violence: the reasons triggering suicide attempts; and suicide: coping and/or solving problems.

\section{RESULTS}

\section{Participants' characteristics}

Nine of the ten participants were female, and one reported being non-binary, i.e., a person who identifies her/himself with the opposite sex and does not fit into the gender assigned to them. These people are neither exclusively and totally women or men; instead they may blend elements of one gender or the other. The adolescents' ages ranged from 12 to 17 , but most were between 14 and 17. Three lived with their mothers, four adolescents lived with both parents, and three lived with their mothers and stepfathers. Some adolescents had siblings, and the grandparents of one adolescent also lived with her family. All were students attending between the $6^{\text {th }}$ grade and $11^{\text {th }}$ grades. The adolescents were receiving treatment from CAPS i between five and 24 months.

\section{Changes in the adolescents' life cycle and violence: the reasons triggering suicide attempts}

When asked about the factors that possibly triggered depressive symptoms, the adolescents reported that the most predominant factors were moving to another city and school and fear and insecurity in making new friends, as the following excerpts show:

I had many friends in the city I used to live. Then, I came here but, I'm shy and having to make new friends was very disturbing. (AF01)

When I came to this new school and started classes in the opposite shift, the depressive symptoms started, I started feeling down. (AF03)

Idon't know what might have triggered the symptoms; changing schools may have to do with it (AF08)

Losing close and loved family members and dealing with conflicting relationships were also mentioned. The adolescents reported they experienced intense suffering when facing difficult life situations.

I started feeling down since my grandmother died. I lived with her, even slept with her, but then I had to start living with my mother [...] I felt lonely and realized that I was really alone. (AF05)

I didn't get along with my family; there were many difficult times, arguments, fights, I didn't feel welcomed where I was. Then, my father died with 12 shots in his back, lost my friends. (AF09)

I wasn't happy with anything that was going on; the relationship with my parents wasn't good, and it bothered me. They'd disagree with me all the time; my relationship with my brothers and my 
boyfriend wasn't good. At school, things were difficult too; I guess a lot of things accumulated (AF04)

Family members physically abused two adolescents, one of them noted that her depressive symptoms started after the psychological and physical violence perpetrated by her father:

The day my dad beat me; actually, since forever. When he'd humiliate me, put me down, call me an idiot, say I didn't know to do anything, I was useless, I felt really down. I have attention deficit disorder, and he'd call me spoiled brat because I need to take medicine but he said I didn't have anything wrong. [...] I guess I've always been depressive since childhood. My father always rejected me, he never showed me much affection; never showed me he loved or like me, never said he loved me: 'daughter, I love you.' (AF02)

In the beginning, one of the adolescents was unsure which event of life might have triggered depressive symptoms because she thought she was the perfect girl. However, throughout the interview, she reported physical violence and sexual abuse:

I don't know; I was a very happy girl, the perfect girl! I was terrific at school, at home [...] / think it was my godmother's aggressions. I used to stay with her for my mother to go to work, and she'd spank me for not being able to do homework. Sometimes, she'd spanked me so hard that my nose would bleed; another time, she punched my chest, and I felt short of breath. There was also what my mother's cousin did to me. He touched me intimately and intrusively. Besides, we don't have a good relationship at home. (AF06)

One adolescent reported difficulty accepting her self-image and interference from "labels imposed by society."

I was 11 years old, and I'd look at the mirror and didn't like what I saw. I couldn't understand why I didn't like myself, I felt so mad looking at myself in the mirror. I didn't like what I saw or what I heard. I'd hear people talking about my appearance, the way I dressed, of my body. (AF07)

\section{Suicide: coping and/or solving problems.}

The adolescents reported that they felt that suicide was the only way to solve their problems. Seven participants said that suicide was the way to end their inner pain and distress, though one considered that it would not probably end her problems, and another participant reported she was praying for protection to avoid suicidal ideation.

I thought that everything would end right there; it'd be over. But I've read about suicide, and it's something that makes sense to me, you may commit suicide, but your problems won't end with death. (AF01)

I thought that if I'd taken my life, all this suffering I feel would end. I wouldn't need to smile to people when I want to cry, pretend I'm someone I am not, stop feeling this pain. Sometimes I pray and ask God to take it out of my head, to guide me and help me think good thoughts. (AF02)

I was tired of fights, of everything, and I thought that taking my life would help to end everything. (AF04)
It was a way to run away from all my problems, see all that, and wish only to take that burden off; every day, it was a struggle, and it gets to the point when you get tired. (AF05)

In my mind, I would no longer feel this pain inside. (AF06)

Basically, I thought that I wouldn't feel anything else; I'd end everything I was feeling at that time, much confusion and pain. (ANB10)

Two adolescents reported they did not feel they belonged to this world, that life is meaningless, and they cannot adapt to their surroundings.

I tried to kill myself because I didn't see meaning in life. (AF08)

I thought that I wasn't fit for this world; I just wanted to leave. I believe in Spiritism, and I know that the life of someone who commits suicide is not easy, but I couldn't bear it any longer; I didn't care what would come after; l just wanted to end it right there. (AF09)

Most of the adolescents attempted suicide many times, or at least more than once, and the means most frequently used was taking high doses of medication, such as muscle relaxers, analgesics, or antipyretics.

I took pills four times; one of the times, I took six muscle relaxers. (AF04)

I've already taken many medications, tried to jump from places, throw myself out of a car, cut myself, took something that is bad for your health; I'd try everything I thought would take my life. (AF05)

Last year, I practically tried to kill myself the entire year, and now during the pandemic too, only that I didn't succeed. I tried to hang myself, took cleaning products, throw myself in front of a truck, and took medications. (AF06)

I took medication twice. Last time, I took 15 pills of acetaminophen, which led me to a liver transplant. (AF09)

One adolescent reported that she witnessed her friends self-inflicting injuries to alleviate their pain, and after observing these episodes, she started to cut herself to minimize her intense emotional pain. As a result, she injured herself for two consecutive years:

The other girls did it, and I didn't know why; they'd say it was to alleviate pain. So, I started doing it by using my pencil sharpener's razor. I cut myself for virtually two years. (AF03)

\section{DISCUSSION}

This study presented the adolescents' reports and perceptions of the intense suffering they experienced during childhood, for losing family members, sexual abuse, and physical and psychological violence, suffering that still permeates their lives. Expressing feelings is an ability learned throughout life, and experiences may encourage or frighten individuals. Additionally, adolescents are still developing their thinking and way of being, and recognizing and expressing their feelings may be challenging in certain situations ${ }^{(6)}$ 
The facts reported by the adolescents in this study reveal the multiple factors that strongly impacted their emotional and social lives. The Bioecological Theory of Human Development formulated by Urie Bronfenbrenner considers that the (micro and macro) context influences human development. The relationship established within the family influences the development of individuals, and it is bidirectional, i.e., relationships influence and are influenced by internal and external contexts. According to this theory, the health-disease continuum is directly related to proximal processes, which are understood as lasting forms of positive or negative interactions in the various contexts, because the way these occur may trigger advancements or setbacks, balances or imbalances, and even cause mental disorders or other diseases ${ }^{(7)}$.

Social withdrawal is a setback that the experiences may have triggered. Prolonged social withdrawal suggests an increased likelihood of developing social and behavioral problems manifested in personal and interpersonal relationships during one's development process. Hence, it might explain the adolescents' difficulty or shyness when experiencing a new context, such as moving to a new town or school, in making new friends. One study conducted with more than 400 adolescents from Coimbra and Aveiro, Portugal, reports that adolescents with a psychological disorder are significantly more likely to feel shame due to feelings of inferiority, devaluation, and self-rejection. They also have a negative perception of themselves, compared to other young individuals. The greater the shame, the more likely one will adopt risk-taking behaviors ${ }^{(8)}$.

Shame is an emotional state of repulsiveness and disgust, which potentially leads to self-injury to avoid or regulate these feelings or as a punishment response ${ }^{(9)}$. One author compares friendships to goods, something of value. In a time when social media is so widespread, the more friends one has, the more in evidence, valued, and remembered one is. Moving to a new town and school decreased the adolescents' number of friends, which were coupled with shame and impeded them from making new friends, making approaching other people even more challenging ${ }^{(10)}$. Changes in an adolescent's life may be traumatic if not discussed and supported.

Traumatic events increase the risk of repeated suicide attempts. Hence, suicide attempts are probably triggered by situations that cause traumatic events throughout life, situations one did not cope with, nor re-signified or positively elaborated. Self-inflicted injuries such as self-mutilation are a way to show that something is causing suffering. When facts torment and cause profound sorrow and pain, self-inflicted injuries are a way to alleviate and momentarily cease sadness. Even though studies report no suicidal intention in self-inflicted injuries, if these injuries become habitual behavior, one may develop suicidal ideation ${ }^{(11)}$.

In this study, the adolescents' reports reveal many reasons that led them to experience stressful events, such as physical and psychological violence, sexual abuse, and the loss of dear ones. The report published in the official journal of the American Academy of Pediatrics in 2016 shows that health workers need to pay attention to adolescents who experienced or are experiencing stressors over their development, especially paying attention to how these situations impact their lives and how they cope with problems. The objective is to enable adolescents to realize that suicide or suicide attempts are not the only way to cope with and solve problems ${ }^{(12)}$.

One study conducted by the Psychiatric Department at Harvard Medical School with 397 adolescents shows that young individuals with suicidal ideation are affected by severe depression, become involved with risk-taking behaviors such as self-inflicted skin burn and scrape injuries ${ }^{(13)}$. However, it also reports that nonsuicidal self-injuries may aggravate distress and increase suicidal tendencies because it momentarily relieves pain ${ }^{(13)}$. Selfinjuries are moderate nonsuicidal injuries one inflicts to oneself not intending to obtain sexual pleasure, without anyone else's intervention, causing physical harm or injuries to alleviate tensions. It is an attempt to keep one self's psychological integrity when the individual does not develop appropriate strategies to cope with unbearable thoughts or the stress they cause ${ }^{(14)}$.

The reasons the adolescents reported as having influenced their emotional decisions included losing a family member and conflicts. The relationships within the family context do not include only expressing feelings toward living people, but important people who are already deceased are also a point of reference and remain alive in the adolescents' memories. Hence, it is possible to nurture positive feelings and follow the model provided by those already gone, especially when they mourn family members. The reports of the adolescents who experienced grief, and extreme sorrow for their losses, are in line with what one author considers, the loss of those who raised you, showed you life and family values, the person who was your reference may lead to depressive feelings and cause the desire not to live ${ }^{(15)}$.

One of the adolescents, who lost her grandmother, whom she considered a mother, needed to move in with her biological mother, someone with whom she did not have any affective bonds. Children and adolescents project idealized images on reference people. During adolescence, individuals are in the process of transforming ideas. Hence, they deal with losing people they consider role models by seeking other compensatory bonds, such as other family members, or an idealized reference such as friends $s^{(15)}$. However, when adolescents do not have other bonds or bonds are fragile, they are even more vulnerable to mourning and health problems. For this reason, they have difficulty elaborating their loss and experience intense suffering. Adolescence is a phase of the vital cycle, the primary characteristic of which is impulsiveness and an urgency to solve their problems so that coping with loss becomes even more difficult. Nonetheless, coping with the loss of a dear one requires time that varies according to each individual. Thus, it is essential to consider how adolescents respond to loss and grief to identify whether grief has become pathological ${ }^{(16)}$.

Considering that grief in both the situations reported by the participants lead to the break of an affective relationship, which, coupled with the vulnerability inherent to the adolescence, probably imposed difficulties on adolescents during the process of acquiring autonomy and independence, and influenced the maintenance and establishment of new affective bonds. One study conducted in the Netherlands suggests that every child and adolescent who lose loved family members, especially in the case of homicides, as one of the adolescents reported, often require specialized mental health services and social services to 
prevent them from becoming vulnerable to grief and find other ways to cope with loss ${ }^{(17)}$.

When loss is coupled with a dysfunctional family, i.e., a maladjusted family context, involving violence, or other conditions not conducive to the formation of the adolescents' personality, it negatively impacts the adolescents' prospects, that is, their occupational identity, character, and the notion of what they consider to be right or wrong ${ }^{(18)}$. In addition, as reported by the official journal of the American Academy of Pediatrics, an unsupported social environment, in which poor relationships are established between parents and children, with stressful situations or arguments with parents, increases the risk of suicide ${ }^{(12)}$.

According to the Bioecological Theory of Human Development, the family is the core of our social system, and for this reason, an adolescent becomes a healthy adult when there are dedicated and actively engaged people who love and spent time with him/her, show interest for what s/he does and want to do in life. Furthermore, the family is one of the most robust and economic contexts to raise and keep a more human and resilient individual who is capable to cope with life adversities, as long as parents are prepared to play their roles ${ }^{(7)}$. Therefore, it is essential to consider the family dynamics of these adolescents and their relationships, being aware that suicide attempts emerge from extreme stress. It is possible to understand that family dynamics permeated by intransigent relationships, violent punishment, and estranged relationships, lead adolescents to deal with much frustration and disappointment as they do not find the support needed to express their feelings and develop healthy coping strategies ${ }^{(18)}$.

The findings of one study conducted at the University of Zurich, Turkey, corroborate this study's results, highlighting the negative consequences of violence on one's emotional development, as violence has a long-lasting effect on people ${ }^{(19)}$. The author also makes an analogy with construction blocks, noting that when the structures of a building are not firm, it collapses under pressure. As other studies show, the violence expressed by the participants exposes the deleterious effect of repeated physical and/or psychological violence and sexual abuse. When an adolescent can no longer bear violence, s/he collapses. In the case of the adolescents addressed in this study, they experienced post-traumatic stress and depressive symptoms that favor an unhealthy lifestyle, especially in the emotional and social spheres. Another study conducted in the Netherlands and Belgium investigating the association between interpersonal violence against children and quality of life in adulthood shows that these events are significantly associated with worsened mental health, leading to somatization, depression, anxiety, and worsened quality of life ${ }^{(20)}$.

Self-image was also reported as something that bothers adolescents. It is known that self-image is a problem related to other factors such as low self-esteem and doubts concerning one's sexual option, and adolescents need to feel well, have a good self-image and self-esteem to develop a mature and self-assured personality. The concept of body image disorder stems from its complexity, and it should be thought of as a variable symptom, seen as part of a complex identity development, which is intrinsic and comprises the adolescent's physical and social aspects ${ }^{(21)}$.

Adolescents have an urgency to solve their problems immediately, which may be explained by their low tolerance to frustration and difficulty in dealing with problems. Hence, when this study's participants could not externalize or solve their problems, they sought other means to bring the situation to an end and attempted to end their lives. Individuals dealing with psychological distress or depressive symptoms frequently manifest the desire to die and/or commit suicide, considering that suicide is the only way to solve their problems ${ }^{(22)}$. Therefore, this study's participants also considered suicide the only alternative to solve their emotional problems. Considering the current context of continuous changes, liquid relationships, a sense that what matters today will no longer make sense tomorrow, the evolution of society, benefits, and the new ways to establish bonds have caused psychological distress in many people, especially the younger ones, who, when unable to cope with challenges, find in death a way to escape reality ${ }^{(23)}$. The reports of most adolescents show that this was their way of thinking, running away from problems, putting an end to everything that was bothering them. They also manifested a feeling of not belonging to this world and society, which made them question the importance of their very existence.

When a young individual feels like a failure, suicide appears as an alternative to alleviate suffering, so they resort to medications or other means to end their lives. The method most frequently adopted to commit suicide was ingesting high doses of medication. A study conducted in the Republic of Slovenia in 2018 addressed the records of individuals who attempted suicide and reports the same results among female participants-drowning and ingesting large amounts of medications appear as the primary means to commit suicide. The second most frequent ways to commit suicide, associated with other means, include poisoning, jumping from heights, and drowning ${ }^{(24)}$. One study conducted in Victoria, Australia, addressed 273 adolescents between 10 and 19 who committed suicide, suggesting that the adolescents who ingest high doses of medications and cut their bodies are at an increased risk of committing suicide ${ }^{(25)}$.

\section{Study Limitations}

This study's limitations include the impossibility of interviewing the adolescents face-to-face due to the measures and protocols determined by the COVID-19 pandemic, which may have partially prevented the establishment of trust between adolescents and the researchers, which would enable them to provide more indepth answers. Another bias that may have interfered in this study's limitation was that the interviewer did not receive specific training to conduct the online interviews.

\section{Contributions to the field}

There is a need to reflect on the role of nurses as health professionals working in the different phases of the vital cycle and different contexts, considering the policies intended to prevent suicide, the tool most frequently used in this profession within the public health sphere. Together with other studies addressing suicide during adolescence, this study is expected to show various relevant aspects that can contribute to future interventions designed to prevent suicide in different contexts, based on the mapping of vulnerable families within the territory under coverage. 


\section{FINAL CONSIDERATIONS}

This study achieved the objective to identify the reasons for attempting suicide from adolescents' perspective, enabling to unveil the reasons triggering depressive symptoms that lead to suicide attempts. The aspects highlighted in this study include family conflicts, psychological and physical violence, and sexual abuse, which intensify these individuals' predisposition to attempt suicide. These factors, coupled with their inexperience in dealing with situations that cause emotional distress and pain, lead the adolescents to consider suicide the only solution for their problems. Thus, putting an end to intense emotional pain, sorrow, and intense suffering caused by stressful events leads adolescents to attempt suicide.

\section{REFERENCES}

1. World Health Organization. Coming of age: adolescent health [Internet]. Geneva: WHO; 2019[cited 2020 Sep 08]. Available from: https:// www.who.int/healthtopics/adolescents/coming-of-age-adolescent-health

2. Santos AA, Barros DB, Lima BM, Brasileiro TC. Automutilação na adolescência: compreendendo suas causas e consequências. Temas Saude. 2018;18(3):120-47. https://doi.org/10.29327/213319.18.3-8

3. Organização Pan-Americana da Saúde. Saúde mental dos adolescentes [Internet]. Brasília, DF: OPAS; 2018[cited $2019 \mathrm{Jul}$ 28]. Available from: https://www.paho.org/bra/index.php?option=com_content\&view=article\&id=5779:fol ha-informativa-saude-mental-dos-adolescentes\&ltemid=839

4. Ministério da Saúde (BR). TabNet: óbitos por causas externas Brasil [Internet]. Brasília, DF: MS; 2017[cited 2020 Sep 08]. Available from: http://tabnet.datasus.gov.br/cgi/tabcgi.exe?sim/cnv/ext10uf.def

5. Minayo MCS. O desafio do conhecimento: pesquisa qualitativa em saúde. São Paulo: Hucitec; 2014.

6. Herzog FF, Ribeiro AC, Welter LS, Senhem GD, Silveira LBTD, Freitas FF. Experiences of adolescents with depressive symptoms in school context. Rev Enferm UFSM. 2020;10:e69. https://doi.org/10.5902/2179769239810

7. Bronfenbrenner U. Bioecologia do desenvolvimento humano: tornando os seres humanos mais humanos. Porto Alegre: Artmed; 2011.

8. Quinteiro AMV, Cunha MO. Autodano, vergonha e traços borderline em adolescentes: o papel mediador da autocompaixão [Dissertação][Internet]. Coimbra: Instituto Superior Miguel Torga. 2020[cited 2020 Sep 19]. Available from: http://repositorio.ismt.pt/ bitstream/123456789/1207/1/Disserta\%C3\%A7\%C3\%A3o_AnaValenteQuinteiro.pdf

9. Taylor PJ, Dhingra K, McDermott E, Dickson JM. Psychological correlates of self-harm within gay, lesbian and bisexual UK university students. Arch Suicide Res. 2020;24(Supp 1):41-56. https://doi.org/10.1080/13811118.2018.1515136

10. Farias CA, Crestani P. A influência das redes sociais no comportamento social dos adolescentes. Rev Cienc Soc [Internet]. 2017[cited 2020 Sep 19];1(2):52-69. Available from: http://revistaadmmade.estacio.br/index.php/cienciaesociedade/article/view/2646

11. Magalhães JRF, Gomes NP, Mota RS, Santos RM, Pereira Á, Oliveira JFD. Repercussões da violência intrafamiliar: história oral de adolescentes. Rev Bras Enferm. 2020;73(1):e20180228. https://doi.org/10.1590/0034-7167-2018-0228

12. Shain B, Committee on Adolescence. Suicide and suicide attempts in adolescents. Pediatrics. 2016;138(1):e20161420. https://doi. org/10.1542/peds.2016-1420

13. Stewart JG, Esposito EC, Glenn CR, Gilman SE, Pridgen B, Gold J, et al. Adolescent self-injurers: comparing non-ideators, suicide ideators, and suicide attempters. J Psychiatr Res. 2017;84:105-12. https://doi.org/10.1016/j.jpsychires.2016.09.03

14. Almeida CM, Horta P. Auto-lesão, auto-mutilação e auto-agressão: a mesma definição? [Internet]. News@fmul. 2010[cited 2020 Sep 21];(16). Available from: http://news.medicina.ulisboa.pt/2010/09/30/auto-lesao-auto-mutilacao-e-auto-agressao-a-mesma-definicao/

15. Silva AC. Adolescência e morte: uma análise psicanalítica de adolescentes em elaboração de luto [Internet]. Manaus: Universidade Federal do Amazonas; 2016[cited 2020 Sep 21]. Available from: http://riu.ufam.edu.br/bitstream/prefix/5407/1/Relatorio_Final_IC_.pdf

16. Silva JCG. O luto no adolescente diante da perda por morte de uma pessoa querida [especialização][Internet]. Belo Horizonte: Universidade Federal de Minas Gerais; 2018[cited 2020 Sep 21]. Available from: https://repositorio.ufmg.br/bitstream/1843/BUOS-BCEHYD/1/trabalho_ de_conclus_o_de_curso_especializa_o_sa_de_do_adolescente__faculdade_de_medicina_ufmg.pdf

17. Alisic E, Groot A, Snetselaar H, Stroeken T, van de Putte E. Parental intimate partner homicide and its consequences for children: protocol for a population-based study. BMC Psychiatry. 2015;15:177. https://doi.org/10.1186 / s12888-015-0565-z

18. Fernandes VM, Zacharias DG. Adolescência, suicídio e redes de apoio: o desejo de morte enquanto grito pela vida. Anais J Pesqui Psicol [Internet]. 2016[cited 2020 Sep 21]. Available from: https://online.unisc.br/acadnet/anais/index.php/jornada_psicologia/article/view/14516/2978

19. Maercker A, Hecker T. Trauma- und Gewaltfolgen--psychische Auswirkungen. Bundesgesundheitsblatt. 2016;59(1):28-34. https://doi. org/10.1007/s00103-015-2259-6

20. Vertommen T, Kampen J, Veldhoven NS, Uzieblo K, Eede FVD. Severe interpersonal violence against children in sport: Associated mental health problems and quality of life in adulthood. Child Abuse Neg. 2018;76:459-68. https://doi.org/10.1016/j.chiabu.2017.12.013

21. Ábrahám I, Jambrik M, John B, Németh AR, Franczia N, Csenki L. A testképtől a testképzavarig. Orv Hetil. 2017;158(19):723-30. https://doi. org/10.1556/650.2017.30752 
22. Penso MA, Sena DPA. A desesperança do jovem e o suicídio como solução. Soc Estado. 2020;35(1):61-81. https://doi.org/10.1590/ s0102-6992-202035010004

23. Santos HGB, Marcon SR, Espinosa MM, Baptista MN, Paulo PMC. Factors associated with suicidal ideation among university students. Rev Latino-Am Enfermagem. 2017;25:e2878. https://doi.org/10.1590/1518-8345.1592.2878

24. Zalar B, Plesničar BK, Zalar I, Mertik M. Suicide and suicide attempt descriptors by multimethod approach. Psychiatr Danub. 2018;30(3):31722. https://doi.org/10.24869/psyd.2018.317

25. Lee S, Dwyer J, Paul E, Clarke D, Treleaven S, Roseby R. Differences by age and sex in adolescent suicide. Aust N Z J Public Health. 2019;43(3):248-53. https://doi.org/10.1111/1753-6405.12877 